\title{
PENENTUAN MODEL ANTRIAN BUS ANTAR KOTA DI TERMINAL MANGKANG
}

\author{
Dwi Ispriyanti ${ }^{1}$, Sugito ${ }^{1}$ \\ ${ }^{1}$ Staf Pengajar Jurusan Statistika FMIPA UNDIP
}

\begin{abstract}
In daily activities, we often face in a situation of queueing. The Queue is dull. Most people have experienced in a queue situation or a waiting situation. It is a part of the state that occurs in a series of operations that are random in a service facility. The Queue can be found easily in a human life, for example bus queue in Terminal Mangkang. It means that a bus wait to be dispatched and from the bus that will go to the service station. Therefore make an arrival and departure of buses not on schedule which resulted in the accumulation of customers in the terminal. To analyze the extent of the effectiveness of terminal Mangkang particularly inter-city terminal Queue theory it is used in the service system in the terminal.
\end{abstract}

Keywords: Queue, Terminal Mangkang

\section{Pendahuluan}

Antrian merupakan suatu fenomena menunggu yang menjadi bagian dari kehidupan sehari-hari manusia. Sebagian besar manusia secara sadar atau tidak sadar, pernah mengalami situasi antrian atau sering disebut dengan situasi menunggu. Situasi antrian sering ditemukan dalam kehidupan sehari-hari, salah satunya yaitu antrian bus di Terminal Mangkang. Terminal Mangkang dibagi menjadi 2 buah terminal yaitu terminal antar kota dan terminal dalam kota. Namun setelah sekian lama pembangunan itu dilakukan, hingga saat ini terminal antar kota pengoperasiannya masih kurang optimal. Untuk itu timbulah masalah bagaimana mengoptimalisasi terminal antar kota tersebut. Salah satu cara untuk mengoptimalkan terminal antar kota yaitu dengan menggunakan teori antrian. Langkahlangkah yang dilakukan yaitu dengan mengadakan penelitian di terminal mangkang untuk mengetahui sejauhmana efektifitas operasional terminal mangkang khususnya terminal antar kota. Pada terminal antar kota terdapat 2 (dua) buah pos pelayanan yaitu pos kedatangan dan pos keberangkatan. Berdasarkan latar belakang diatas dapat dituliskan masalah sebagai berikut:

1. Bagaimana menentukan model antrian bus yang tepat untuk Terminal Mangkang khususnya Terminal antar kota?

2. Bagaimana menentukan ukuran kinerja sistem antrian bus sehingga efisiensi pelayanan di Terminal Mangkang khususnya terminal antar kota?

Permasalahan yang digunakan yaitu bus antar kota bertindak sebagai pelanggan dan terminal mangkang bertindak sebagai pelayan.

\section{Tinjauan Pustaka}

\subsection{Gambaran Umum Terminal Mangkang}

Terminal Mangkang diresmikan oleh Menteri Perhubungan Jusman Safeii Djamal pada hari Senin 10 Agustus 2009. Sesuai dengan desain pembangunannya, Terminal Mangkang diharapkan bisa menampung 4.200 penumpang per hari. Terminal Mangkang terletak di sebelah barat pusat kota yang berjarak sekirar $15 \mathrm{~km}$ atau letaknya berbatasan 
langsung dengan Kabupaten Kendal. Terminal ini dibangun dengan luas bangunan $16.000 \mathrm{~m}^{2}$ yang melayani angkutan antar kota, angkutan dalam kota dan angkutan pedesaan.

\subsection{Teori Antrian}

Situasi menunggu untuk mendapatkan jasa pelayanan akan membentuk suatu garis tunggu. Garis-garis tunggu ini, sering disebut dengan antrian (queues), karena fasilitas pelayanan (server) adalah relatif mahal untuk memenuhi permintaan pelayanan dan sangat terbatas. Antrian yang sangat panjang dan terlalu lama untuk memperoleh giliran pelayanan sangat meyebalkan. Rata-rata lamanya waktu menunggu (waiting time) sangat tergantung kepada rata-rata tingkat kecepatan pelayanan (rate of service). Teori antrian pertama kali ditemukan dan dikembangkan oleh A.K. Erlang, seorang insinyur dari Denmark yang bekerja pada perusahaan telepon di Kopenhagen pada tahun 1909.

\subsection{Unsur Dasar Antrian}

Dalam proses antrian terdapat tujuh unsur penting yang berkitan dengan sistem antrian tersebut, yaitu ${ }^{[4]}$ :

1. Distribusi kedatangan (Pola kedatangan)

2. Distribusi waktu pelayanan (Pola pelayanan)

3. Fasilitas pelayanan

4. Disiplin pelayanan

5. Ukuran antrian

6. Sumber pemanggilan

7. Perilaku manusia

\subsection{Notasi Kendall}

Notasi Kendall digunakan untuk merinci ciri dari suatu antrian. Notasi yang sesuai untuk meringkaskan karakteristik utama dari antrian paralel telah secara universal dibakukan dalam format berikut:

$$
(\mathrm{a} / \mathrm{b} / \mathrm{c}):(\mathrm{d} / \mathrm{e} / \mathrm{f})
$$

a : Distribusi kedatangan

$\mathrm{b}$ : Distribusi waktu pelayanan

c: Fasilitas pelayanan atau banyaknya tempat service (stasiun serial paralel atau jaringan)

d: Disiplin pelayanan (FIFO, LIFO, SIRO) dan prioritas pelayanan

e: Ukuran sistem dalam antrian (terhingga atau tak terhingga)

f : Sumber pemanggilan (terhingga atau tak terhingga) ${ }^{[4]}$

\subsubsection{Distribusi Kedatangan dan Distribusi Waktu Pelayanan}

Pola kedatangan para pelanggan biasanya dicirikan oleh waktu antar-kedatangan, yaitu waktu antara kedatangan dua pelanggan yang berurutan pada suatu fasilitas pelayanan. Pola ini dapat bergantung pada jumlah pelanggan yang berada dalam sistem ataupun tidak bergantung pada keadaan sistem tersebut. Bila bentuk kedatangan ini tidak disebut secara khusus, maka dianggap bahwa pelanggan tiba satu persatu. Asumsinya adalah kedatangan pelanggan mengikuti suatu proses dengan distribusi probabilitas tertentu. Distribusi probabilitas yang sering digunakan adalah distribusi Poisson, Asumsi distribusi Poisson menunjuk bahwa kedatangan pelanggan sifatnya acak dan mempunyai rata-rata kedatangan sebesar lamda $(\lambda)$. Bila kedatangan individu-individu mengikuti suatu distribusi Poisson, maka waktu antar kedatangan atau interarrival time (yaitu waktu 
antara kedatangan setiap individu) adalah random dan mengikuti suatu distribusi Eksponensial $^{[2]}$.

Distribusi kedatangan dibagi menjadi dua, yaitu:

a. Kedatangan secara individu (single arrivals).

b. Kedatangan secara kelompok (bulk arrivals).

Pola pelayanan biasanya dicirikan oleh waktu pelayanan (service time), yaitu waktu yang dibutuhkan seorang pelayan untuk melayani seorang pelanggan. Waktu pelayanan dapat bersifat deterministik, atau berupa suatu variabel acak yang distribusi probabilitasnya dianggap telah diketahui. Besaran ini dapat bergantung pada jumlah pelanggan yang telah berada di dalam fasilitas pelayanan, atau tidak bergantung pada keadaannya. Yang perlu diperhatikan apakah seorang pelanggan hanya dilayani oleh satu pelayan atau suatu pelangan ini membutuhkan suatu barisan pelayan. Bila tidak disebutkan secara khusus, maka anggapan dasarnya adalah bahwa satu pelayan saja dalam melayani secara tuntas urusan seorang palanggan ${ }^{[1]}$. Pola pelayanan berkaitan dengan berapa banyak fasilitas pelayanan yang dapat disediakan. Pola pelayanan terbagi dalam dua komponen penting, yaitu :

a. Pelayanan secara individual (single service).

b. Pelayanan secara kolompok (bulk service).

\subsubsection{Fasilitas Pelayanan dan Disiplin Pelayanan}

Fasilitas pelayanan berkaitan erat dengan baris antrian yang akan dibentuk. Fasilitas pelayanan ini terbagi dalam tiga bentuk, yaitu :

a. Bentuk series, yaitu pelayanan yang berada dalam satu garis lurus ataupun garis melingkar.

b. Bentuk paralel, yaitu pelayanan yang berada dalam beberapa garis lurus di mana antara garis yang satu dengan yang lain berbentuk paralel.

c. Bentuk network station, yaitu pelayanan yang dapat didesain secara series dengan pelayanan lebih dari satu pada setiap stasiun.

Disiplin pelayanan adalah aturan di mana para pelanggan dilayani atau disiplin pelayanan (service discipline) yang memuat urutan (order) para pelanggan menerima layanan ${ }^{[2]}$. Aturan pelayanan menurut urutan kedatangan dapat didasarkan pada:

1. Pertama Masuk Pertama Keluar (FIFO)

FIFO (First In First Out) merupakan suatu peraturan dimana yang akan dilayani terlebih dahulu adalah pelanggan yang datang terlebih dahulu.

2. Yang Terakhir Masuk Pertama Keluar (LIFO)

LIFO (Last In First Out) merupakan antrian dimana yang datang paling akhir adalah yang dilayani paling awal.

3. Pelayanan dalam Urutan Acak (SIRO)

SIRO (Service In Random Order) dimana pelayanan dilakukan secara acak.

4. Pelayanan Berdasarkan Prioritas (PRI)

Merupakan suatu peraturan dimana pelayanan didasarkan pada prioritas khusus.

\subsubsection{Ukuran dalam Antrian dan Sumber Pemanggilan}

Besarnya antrian pelanggan yang akan memasuki fasilitas pelayanan pun perlu diperhatikan. Ada 2 desain yang dapat dipilih untuk menentukan besarnya antrian, yaitu ${ }^{[2]}$ :

1. Ukuran kedatangan secara tidak terbatas

2. Ukuran kedatangan secara terbatas 
Suatu karakteristik yang perlu diketahui dari sumber pemanggilan ini adalah ukurannya (jumlahnya), yaitu jumlah total unit yang memerlukan pelayanan dari waktu ke waktu atau disebut jumlah total pelanggan potensial. Ini bisa dianggap terbatas ataupun tidak terbatas. Untuk jumlah pelanggan yang terbatas jumlah unit dalam sistem antrian akan mempengaruhi jumlah pelanggan potensial di luar sistem pada setiap waktu.

\subsection{Ukuran Steady-state dari Kinerja Sistem}

Asumsi steady state akan terpenuhi bila $\lambda<\mu$ sehingga $\rho<1$ dimana $\lambda$ adalah jumlah rata-rata laju kedatangan dan $\mu$ adalah rata-rata laju pelayanan. Setelah steady-state dapat dihitung ukuran karakteristik kinerja dari situasi antrian yang dapat digunakan untuk menganalisis bentuk antrian tersebut.

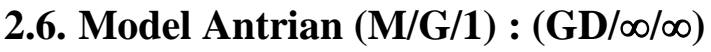

Ciri-ciri model ini ialah distribusi kedatangannya berdistribusi poisson dan distribusi pelayanannya berdistribusi umum (General). Model ini berlaku untuk semu disiplin antrian kecuali untuk disiplin prioritas pelayanan ${ }^{[3]}$. Rumus untuk menghitung jumlah pelanggan yang diperkirakan dalam antrian (Lq) adalah:

$$
L_{q}=\frac{\lambda^{2}(E[t])^{2}+\lambda^{2} \operatorname{var}[t]}{2(1-\lambda E[t])}
$$

dengan:

Jumlah pelanggan yang diperkirakan dalam sistem yaitu : $L_{s}=L q+\lambda E[t]$

Waktu menunggu yang diperkirakan dalam antrian yaitu $: \mathrm{Wq}=\frac{L q}{\lambda}$

Waktu menunggu yang diperkirakan dalam sistem $: \mathrm{Ws}=\mathrm{Wq}+E[t]$

\section{Metodologi Penelitian}

Penelitian ini dilakukan dengan mengambil sampel data selama dua hari mulai pukul 05.00 hingga pukul 17.00. Penelitian dilakukan di Terminal Mangkang pada tanggal 6 Agustus 2012 hingga 7 Agustus 2012. Observasi dilakukan untuk mendapatkan data jumlah kedatangan bus, waktu kedatangan bus, dan waktu pelayanan bus kota di terminal. Adapun prosedur penelitiannya disajikan pada Gambar 1 berikut: 


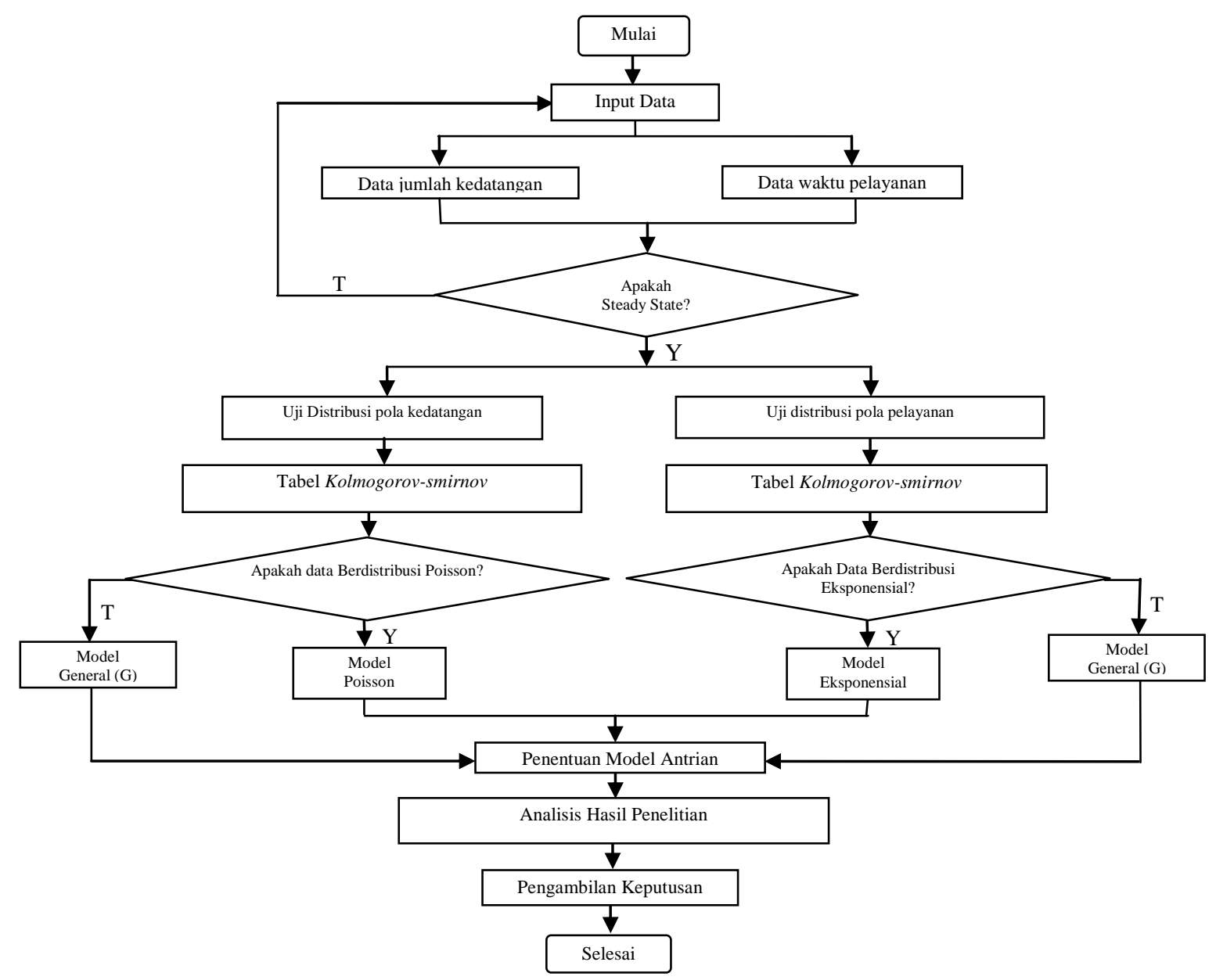

Gambar 1. Prosedur Penelitian

\section{Hasil dan Pembahasan}

Sistem antrian di Terminal antar Kota di Mangkang dibagi menjadi dua pos pelayanan yaitu pos kedatangan dan pos pelayanan penumpang dan pos pemberangkatan. Untuk pos kedatangan, pelanggan dilayani oleh satu server. Sedangkan pos pelayanan penumpang terdapat 4 jalur pelayanan. Untuk lebih jelasnya sistem antrian pada Terminal Mangkang dapat dilihat pada Gambar 2. 


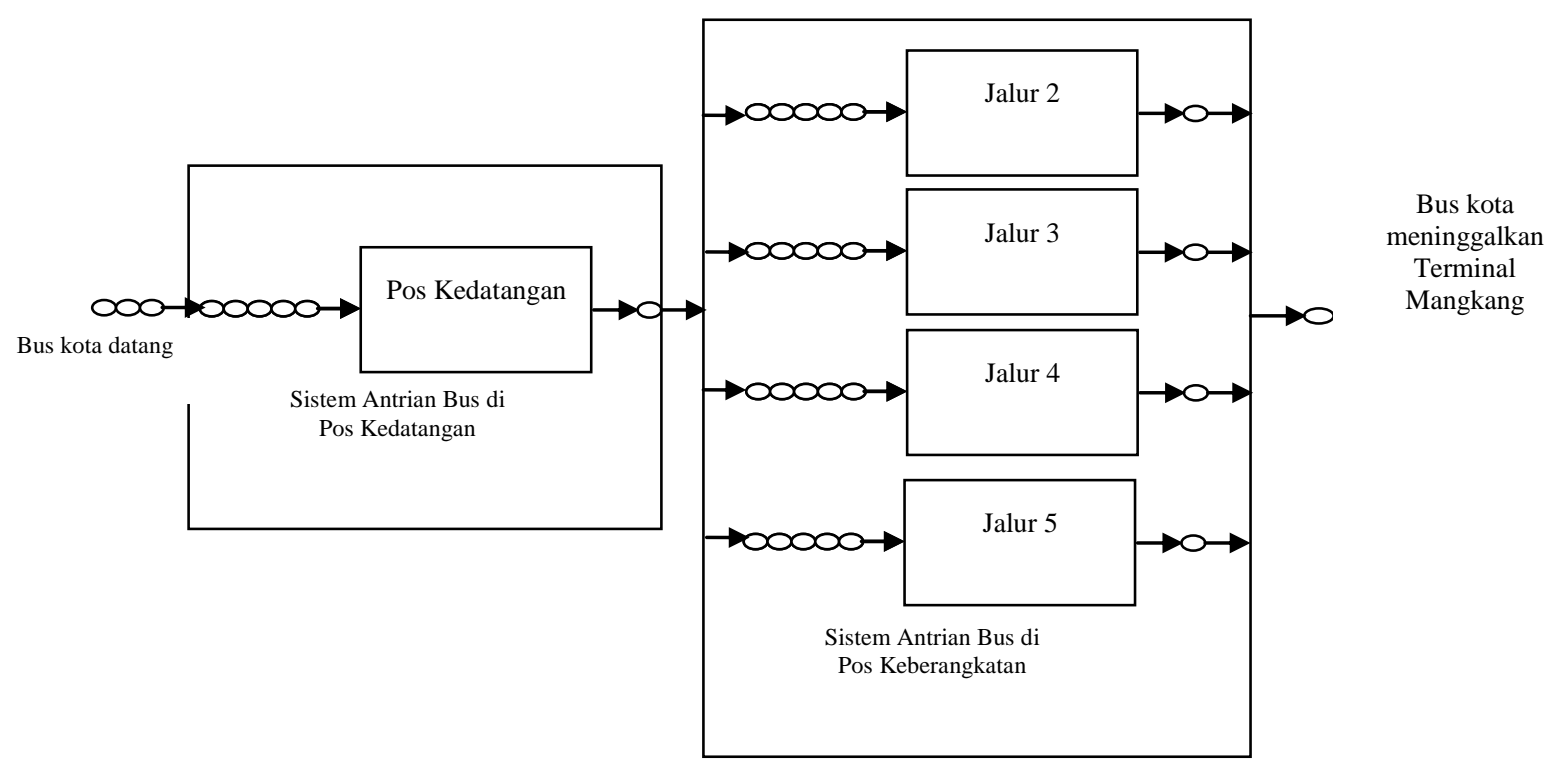

Gambar 2. Sistem Antrian Bus di Terminal Mangkang

\subsection{Analisis Steady State}

Analisis data awal akan dimulai dengan menghitung faktor utilisasi $(\rho)$ untuk masingmasing pos pelayanan. Ukuran steady-state dari kinerja sistem pelayanan dapat diperoleh dari data jumlah kedatangan pada obyek penelitian dan data waktu pelayanan dengan menghitung probabilitas dari sistem pelayanan. Kondisi steady-state harus terpenuhi sehingga sistem pelayanan dapat mencapai keadaan yang stabil. Kemudian akan dilakukan analisis dengan menggunakan teori antrian untuk memecahkan masalah yang ada secara khusus dan akan dihitung nilai $\rho$ sebagai berikut:

Tabel 1. Analisis Steady-State

\begin{tabular}{|c|l|c|c|c|}
\hline \multicolumn{5}{|c|}{ Bus Antar Kota } \\
\hline Pos & \multicolumn{1}{|c|}{ Jurusan } & Lamda $(\boldsymbol{\lambda})$ & Miu $(\boldsymbol{\mu})$ & Rho $(\rho)$ \\
\hline \multirow{3}{*}{ Kedatangan } & Semua jurusan & 13,8346 & 112,201 & 0,1233 \\
\hline \multirow{3}{*}{ keberangkatan } & Jalur 2 - Tegal Cirebon Ekonomi & 2 & 3,5026 & 0,5710 \\
\cline { 2 - 5 } & Jalur 3 - Solo & 4,95652174 & 400,595789 & 0,01237288 \\
\cline { 2 - 5 } & Jalur 4 - Tegal, Cirebon Patas & 8,17391304 & 68,3912692 & 0,11951691 \\
\cline { 2 - 5 } & Jalur 5 - Jakarta, Bandung & 2,277778 & 190,668348 & 0,01194628 \\
\hline
\end{tabular}

Berdasarkan Tabel 1 terdapat tidak terdapat nilai $\rho<1$, artinya tidak terdapat ratarata kedatangan pelanggan melebihi kapasitas rata-rata kecepatan pelayanan sehingga memenuhi kondisi steady-state. Untuk itu dapat dilakukan analisis kecocokan model untuk mendapatkan karakteristik dari sistem pelayanan.

\subsection{Uji Kecocokan Model}

Sebelum melakukan analisis antrian terlebih dahulu dilakukan analisis kecocokan model apakah distribusi kedatangan mengikuti distribusi Poisson dan distribusi pelayanan 
mengikuti distribusi Eksponensial. Hasil dari pengolahan data uji kolmogorov, didapat hasil seperti pada Tabel 2 berikut:

Tabel 2. Uji Kecocokan Data Jumlah Kedatangan

\begin{tabular}{|c|c|c|c|c|c|}
\hline Pos & Jurusan & D & $\mathbf{D} *(\boldsymbol{\alpha})$ & Keputusan & Kesimpulan \\
\hline Kedatangan & Semua jurusan & 0,065 & 0,2050 & $\begin{array}{c}\mathrm{H}_{0} \text { Diterima karena } \\
\text { nilai } \mathrm{D}<\mathrm{D}^{*}(\alpha) \\
\end{array}$ & $\begin{array}{c}\text { Data berdistribusi } \\
\text { Poisson }\end{array}$ \\
\hline \multirow{4}{*}{ Keberangkatan } & $\begin{array}{c}\text { Jalur } 2-\text { Tegal } \\
\text { Cirebon Ekonomi } \\
\end{array}$ & 0,041 & 0,269 & $\begin{array}{c}\mathrm{H}_{0} \text { Diterima karena } \\
\text { nilai } \mathrm{D}<\mathrm{D}^{*}(\alpha)\end{array}$ & $\begin{array}{c}\text { Data berdistribusi } \\
\text { Poisson }\end{array}$ \\
\hline & Jalur 3 - Solo & 0,047 & 0,2005 & $\begin{array}{c}\mathrm{H}_{0} \text { Diterima karena } \\
\text { nilai } \mathrm{D}<\mathrm{D}^{*}(\alpha)\end{array}$ & $\begin{array}{c}\text { Data berdistribusi } \\
\text { Poisson }\end{array}$ \\
\hline & $\begin{array}{c}\text { Jalur } 4 \text { - Tegal } \\
\text { Cirebon PATAS }\end{array}$ & 0,120 & 0,2005 & $\begin{array}{c}\mathrm{H}_{0} \text { Diterima karena } \\
\text { nilai } \mathrm{D}<\mathrm{D}^{*}(\alpha)\end{array}$ & $\begin{array}{c}\text { Data berdistribusi } \\
\text { Poisson }\end{array}$ \\
\hline & $\begin{array}{c}\text { Jalur } 5 \text { - Jakarta } \\
\text { Bandung }\end{array}$ & 0,094 & 0,309 & $\begin{array}{c}\mathrm{H}_{0} \text { Diterima karena } \\
\text { nilai } \mathrm{D}<\mathrm{D} *(\alpha)\end{array}$ & $\begin{array}{c}\text { Data berdistribusi } \\
\text { Poisson }\end{array}$ \\
\hline
\end{tabular}

Tabel 3. Uji Kecocokan Data Waktu pelayanan

\begin{tabular}{|c|c|c|c|c|c|}
\hline Pos & Jurusan & $\mathrm{D}$ & $\mathrm{D}^{*}(\alpha)$ & Keputusan & Kesimpulan \\
\hline \multirow{5}{*}{ Kedatangan } & Semua jurusan & 0,229 & 0,0681 & $\begin{array}{c}\mathrm{H}_{0} \text { Diterima karena } \\
\text { nilai } \mathrm{D}>\mathrm{D} *(\alpha)\end{array}$ & $\begin{array}{c}\text { Data berdistribusi } \\
\text { General }\end{array}$ \\
\hline \multirow{5}{*}{ Keberangkatan } & $\begin{array}{c}\text { Jalur 2 - Tegal } \\
\text { Cirebon Ekonomi }\end{array}$ & 0,202 & 0,1963 & $\begin{array}{c}\mathrm{H}_{0} \text { Diterima karena } \\
\text { nilai D }>\mathrm{D}^{*}(\alpha)\end{array}$ & $\begin{array}{c}\text { Data berdistribusi } \\
\text { General }\end{array}$ \\
\cline { 2 - 6 } & Jalur 3 - Solo & 0,284 & 0,1274 & $\begin{array}{c}\mathrm{H}_{0} \text { Diterima karena } \\
\text { nilai D }>\mathrm{D}^{*}(\alpha)\end{array}$ & $\begin{array}{c}\text { Data berdistribusi } \\
\text { General }\end{array}$ \\
\cline { 2 - 6 } & $\begin{array}{c}\text { Jalur 4 - Tegal } \\
\text { Cirebon PATAS }\end{array}$ & 0,379 & 0,0992 & $\begin{array}{c}\mathrm{H}_{0} \text { Diterima karena } \\
\text { nilai D }>\mathrm{D}^{*}(\alpha)\end{array}$ & $\begin{array}{c}\text { Data berdistribusi } \\
\text { General }\end{array}$ \\
\cline { 2 - 7 } & $\begin{array}{c}\text { Jalur 5 - Jakarta } \\
\text { Bandung }\end{array}$ & 0,267 & 0,2097 & $\begin{array}{c}\mathrm{H}_{0} \text { Diterima karena } \\
\text { nilai D }>\mathrm{D}^{*}(\alpha)\end{array}$ & $\begin{array}{c}\text { Data berdistribusi } \\
\text { General }\end{array}$ \\
\hline
\end{tabular}

Setelah dilakukan uji kecocokan distribusi maka dapat ditentukan model antriannya. Untuk Pos Kedatangan model antriannya yaitu M/G/1 : GD/ $/ \infty$, dengan jumlah server

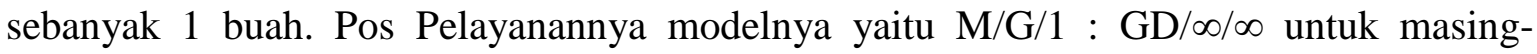
masing jurusan.

\subsection{Analisis Ukuran Kinerja Sistem Antrian Terminal Mangkang}

Setelah dilakukan analisis steady-state dan uji kecocokan model, langkah selanjutnya yaitu melakukan analisis kinerja sistem antrian dengan menggunakan program WinQSB akan diperoleh hasil akhir model antrian seperti terlihat pada Tabel 4. 
Tabel 4. Perolehan Hasil Akhir Analisis Antrian

\begin{tabular}{|c|c|c|c|c|c|c|}
\hline Pos & Jurusan & Model & Ls & $\mathrm{Lq}$ & Ws & $\mathrm{Wq}$ \\
\hline Kedatangan & Semua jurusan & $\begin{array}{l}\mathrm{M} / \mathrm{G} / 1: \\
\mathrm{GD} / \infty / \infty\end{array}$ & 0,9510 & 0,38 & 0,19 & 0,4755 \\
\hline \multirow{4}{*}{$\begin{array}{c}\text { Pelayanan } \\
\text { Penumpang }\end{array}$} & Jalur 2 & $\begin{array}{l}\mathrm{M} / \mathrm{G} / 1: \\
\mathrm{GD} / \infty / \infty\end{array}$ & 1,2789 & 0,7079 & 0,6394 & 0,3539 \\
\hline & Jalur 3 & 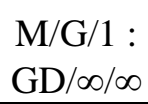 & 0,2024 & 0,19 & 0,0408 & 0,0383 \\
\hline & Jalur 4 & $\begin{array}{l}\mathrm{M} / \mathrm{G} / 1: \\
\mathrm{GD} / \infty / \infty\end{array}$ & 0,1523 & 0,0330 & 0,0186 & 0,0040 \\
\hline & Jalur 5 & 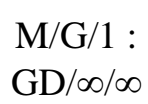 & 0,0119 & 0,0001 & 0,0052 & 0,0034 \\
\hline
\end{tabular}

\section{Kesimpulan}

Teori antrian dapat digunakan untuk memecahkan suatu masalah dalam suatu fasilitas pelayanan. Dengan teori antrian, dapat diperoleh suatu model antrian yang dapat digunakan untuk mengetahui apakah suatu fasilitas pelayanan sudah bekerja secara optimal. Dari hasil penelitian dan analisis yang telah dilakukan, maka dapat disimpulkan beberapa hal sebagai berikut:

a. Model antrian yang terjadi di Terminal Mangkang untuk terminal antarkota adalah:

1. Model antrian yang ada pada pos kedatangan Terminal Mangkang adalah model (M/G/1):(FIFO/敒) artinya pola kedatangan berdistribusi Poisson dan pola pelayanan berdistribusi umum (general). Pada fasilitas pelayanan ini terdapat 1 buah pelayanan dengan aturan pelayanannya yaitu pelanggan yang pertama datang akan dilayani pertama serta dapat menampung tak hingga pelanggan yang boleh memasuki sistem sebagai sumber untuk sistem pelayanan di pos kedatangan.

2. Pada pos pelayanan penumpang terdapat 4 jalur pelayanan sesuai dengan jurusannya masing-masing yang dirangkai secara paralel. Model antrian yang ada pada pos pelayanan penumpang pada masing-masing jalur adalah model

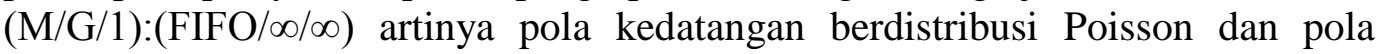
pelayanan berdistribusi umum. Pada fasilitas pelayanan ini terdapat 1 buah pelayanan untuk masing-masing jalur dengan aturan pelayanannya yaitu pelanggan yang pertama datang akan dilayani pertama serta dapat menampung tak hingga pelanggan yang boleh memasuki sistem sebagai sumber untuk sistem pelayanan di masing-masing jalur pelayanan pada pos pelayanan penumpang.

b. Berdasarkan perhitungan dan analisis secara keseluruhan dapat disimpulkan bahwa sistem pelayanan Terminal mangkang masih berjalan kurang optimal. Hal ini disebabkan karena waktu menunggu pelanggan dalam sistem masih rendah sehingga terminal ini masih terlihat sepi. Oleh karena itu terminal ini masih dijadikan tempat transit bagi bus antar kota. 


\section{DAFTAR PUSTAKA}

1. Bronson, R., Teori dan Soal-Soal Operation Reserch, PT Gelora Aksara Pratama, 1991.

2. Kakiay, T. J., Dasar Teori Antrian Untuk Kehidupan Nyata, Penerbit Andi, Yogyakarta, 2004.

3. Siagian, P., Penelitian Operasional : Teori dan Praktek, Universitas Indonesia Press, Jakarta, 1987.

4. Taha, H. A., Riset Operasi Jilid 2, Binarupa Aksara, Jakarta, 1996. 